Preliminary communication UDC 159.97:82(045)

1 Foucault, M.

doi: $10.21464 / \mathrm{sp} 35103$

Received: 18 June 2020

\title{
Labinot Kelmendi
}

University of Prishtina, Faculty of Philosophy, Rr. Nënë Tereza, p.n., XK-10000 Prishtina

labinot.kelmendi@uni-pr.edu

\section{Madness and Literature: Foucault's Encounter}

\begin{abstract}
The purpose of this paper is to outline the connection between literature, madness and language in Foucault's philosophy. In the first part of the paper, these three discursive bases are situated in the "cosmos of madness" in the sense of what Serres calls "the archaeology of psychology" and Caputo "the deconstruction of psychology". This part marks the language of literature as a decomposing space of the "tribunal of the cogito" (Derrida). The second part explicates the impetus of "literature language", trying to promote lunatic manifestations that are the works of three authors, Dostoevsky, De Sade and Artaud, and how their work has a symbiotic connection with the work of Foucault. The paper ends with the connection of the unreasonable and parrēsia as an opportunity that could be manifested only in literature as a habitus to exist in. Finally, as Foucault notes, the "language of literature" is the "language of madness" or the possibility of freedom of the expression of our Being.
\end{abstract}

\section{Keywords}

Michel Foucault, madness, literature, language, parrēsia, unreasonable

\section{"Literature is the most agreeable way of ignoring life." Fernando Pessoa}

"What interested me and guided me was a certain presence of madness in literature."

Michel Foucault

"Du côté de la folie"3

The general premise of this paper is not to enter into controversy over the meaning of madness and insanity through clinical or psychotherapeutic discourse, but to talk about insanity and madness from the prism of 'exclusion' (Foucault), which means looking at the problem from a cultural point of view. Madness cannot be found in the 'raw state', the sensitivity to it can only be

Cf. Fernando Pessoa, The Book of Disquiet, translated by Richard Zenith, Penguin Books, New York - London 2002.

2

Cf. Michel Foucault, Foucault Live (Interviews, 1961-1984), Sylvère Lotringer (ed.), translated by Lysa Hochroth, John Johnston, Semiotext(e), New York 1996.

3

This phrase is borrowed from J. G. Mequior's book Foucault, which in the literal translation means 'on the side of madness', and that will greatly orient the direction of the paper because Foucault's approach inevitably leads us to the dialogue between madness and reason, and criticism of the detachment of this dialogue. - José Guilherme Merquior, Foucault, University of California Press, Berkeley - Los Angeles 1985. All the literature books selected for this paper were written by 'lunatics' and people with spiritual problems, as they would be called by the 'doctors of the soul'. The goal was to mark their 'history of the present'. 
grasped within social context; oppression and exclusion are not sensitivities and aesthetic artefacts out of existence in society ${ }^{4}$ or, as Foucault outlines:

"... madness was present on the social horizon as an aesthetic or daily fact."

The archaeology of psychology (Serres) is an alternative reading of the history of madness; it has also deconstructed the previous interpretations of reading this history - readings that have been written by those who have done "The Great Confinement" (Foucault). Caputo, a philosopher of radical hermeneutics, attributes an interesting equivalence to this deconstruction. Heidegger, according to him, "deconstructs the history of ontology", and Foucault "deconstructs the history of psychology". " If we go back to this historical reading mentioned above, it awakens the "Dionysus archivist" 8 to explore the scourges and stratifications of the 'Apollonian' repression - these archives make this search or examination more authentic because it challenges and prevails over our hitherto interpretations about madness, ${ }^{9}$ as Derrida asserts:

“... (letting) madness speaking about itself." 10

The purpose of madness is not to present a linear meta-narrative or a historicist understanding regarding the issue mentioned but to show how these kind of views, here referring to those mentioned above, have excluded madness from any life activity. This "historical a priori" 11 does not reveal the coherent and continuous connection of the stages; its idea is to tell the "history of discontinuity" 12 and madness as a moment of this "history of the present". ${ }^{13}$ Explicitly, this means to see this whole movement as a moment of liberation from "transcendental narcissism". ${ }^{14}$ Thus, the story of madness is not subject to transcendental interpretation on this issue. Moreover, detected are those "intra-histories" 15 whose vocation has been deafened; those "small narratives" 16 that expose the "anarchitecture of oppression" which uprooted the dialogue between madness and reason under the rational delirium of creating the perfect polis. The consequence of the "entelecheia of polis" is the creation of an essentially moral, scientific/practical/medical legal basis under the banner of "pathology'/disease and the theory of cogito ergo sum (Descartes), that as a lumen naturale ${ }^{17}$ under the "tribunal of cogito"18 (Derrida) removes the problem of madness with the exercise of reason ${ }^{19}$ which, as a marking, uses denigrating (epistemic/ontological) word formation for the excluded as the Other 'unreasonable'. Descartes' axiom 'I think therefore I cannot be mad. ${ }^{\prime 20}$ is the culprit for seceding all relations of madness and truth. Because "the mad does not think", Descartes excludes madness from the scheme of methodical doubt and even from the plane of sensory illusion. The repressive symptomatic Cartesian order excludes madness from the place occupied by rationalist philosophy, which deprives it of being and gives it the 'status of non-being, ${ }^{21}$ by insulting, humiliating and ultimately silently convicting it, as literary critic Shoshana Felman notes:

“... expels madness from the confines of culture and robs it of its language, condemning it to Silence." 22

To understand this discursive architecture of madness, we must refer to a passage of Foucault, where the subject loses his freedom in two ways:

“... the natural movement of his madness, and the juridical movement of interdiction, which brought him under the power of an Other - other people in general, effectively represented by his guardian. The other form of alienation was the sudden consciousness, within his own society, that a madman was a stranger in his own land. Rather than being freed from his responsibil- 
ity he was made to feel guilty by association and kinship with other bearers of guilt: he became the Other, the Outsider, the Excluded." 23

The journey from the Middle Ages $^{24}$ to the cosmos of madness/insanity detects four key moments in the constitution of this cosmos. The first moment is in the Middle Ages, where we try to see madness as something divine and sacred. The second moment is also known as the beginning of the dialogue

Michel Foucault, "Madness Exists Only in Society", in: M. Foucault, Foucault Live, pp. $7-9$, p. 8.

5

Ibid.

Foucault's interpreters detected that a history of madness cannot be written by those who have given the status of 'pathology' to madness through language and action, who have constituted it as a disease and have been the key factor of what he calls "The Great Confinement". Lawlord and Pulumbo claim: "Confinement was the practice that concretely accomplished the ethical decision that animated the moral perception of the Classical Age. (...) Confinement is the concrete manifestation of an entire readjustment of the ethical world." - Leonard Lawlor, Daniele J. Palumbo, "The Origin of Parrēsia in Foucault's Thinking: Truth and Freedom in the History of Madness", in: David Scott (eds.), Understanding Foucault: Understanding Modernism, Bloomsbury, New York - London 2017, pp. 21-37, p. 24.

John Caputo, "On Not Knowing Who We Are: Madness and Hermeneutics, and the Night of Truth in Foucault", in: John Caputo, Mark Yount, Foucault and the Critique of Institutions, The Pennsylvania State University Press, Pennsylvania 1993, pp. 233-262, p. 233.

8

Peter Sloterdijk, Philosophical Temperaments: From Plato to Foucault, translated by Thomas Dunlap, Columbia University Press, New York 2013, p. 97

J. G. Merquior, Foucault, p. 26.

10

Jacques Derrida, Writing and Difference, translated by Alan Bass, Routledge, New York - London 2001, p. 39.

11

For Foucault, archeology detects unconscious and anonymous forms of thought which are outlined and known as the Episteme. An Episteme is a 'historical a priori' recognition that sets in the historical system of non-formal knowledge (Merquior) and consequently constitutes archaeological thought.

12

Michel Foucault, The Archeology of Knowledge, translated by A. M. Sheridan Smith, Routledge, New York - London 2002, p. 202. 13

J. G. Merquior, Foucault, p. 18.

14

M. Foucault, The Archeology of Knowledge, p. 203.

15

Cf. Miguel de Unamuno, En torno al casticismo, Espasa-Calpe, Madrid 1968.

16

According to Mieke Ball, known for her concept of narratology, 'small narratives' are those local narratives that are an inevitable part of our daily lives. Ball claims that these local narratives have "already replaced the big narratives, and states that small narratives can take all forms and operate in all media. They constitute the cultural moment". - Mieke Ball, "Narrativa është mjeti ynë më i mire" ["Narrative is Our Best Tool"], Symbol 5 (2015), interview (led by Ag Apolloni), pp. 8-28, p. 28. Cf. Mieke Ball, Narratology: Introduction to the Theory of Narratives, University of Toronto Press, Toronto - London 2009.

17

Muhamedin Kullashi, a philosopher from Kosovo, connects the thinking of our existence with the light of the mind (lumen naturale): "... thanks to it, man makes himself human while making the world human. Thanks to the natural light of the mind (lumen naturale), man gives meaning to his existence, extracted from the darkness of nothingness and meaninglessness in his world." - Muhamedin Kullashi, Vetëpërkufizimi i Njeriut, Rilindja, Prishtinë 1987, p. 115.

18

J. Derrida, Writing and Difference, p. 37.

19

Descartes' fear is presented in the chapter on the great confinement in Foucault's book History of Madness. Foucault argues that Des- 
between madness and reason, the moment where madness has a share in the truth. ${ }^{25}$ In this period, madness is seen as something beyond reason; something we have to exclude in the form of pilgrimage in the 'ship of fools' to find the reason but doesn't make the 'clear cut' if we could say with society. This period is characterized by the coexistence of wisdom and madness articulated with the term Lucian morosophous ${ }^{26}$ - which means the wisely mad or madly wise.$^{27}$ Classical rationalism is the third period and is metaphorically marked by the passage from the ship to the hospital, where the dialogue between madness and reason is interrupted; madness is already categorized as a pathological disease and disorder. This medical presumption is helped by the legal exception complemented by the moral one. As J. G. Merquior states:

"Rationalist reason put unreason under 'pathological' curse fraught with ethical overtones." 28

We can see that classical rationality cannot be removed from metaphysical resentment, which implies that Nietzsche warned us that Christian morality would remain an inherent part of Western thought. This, inherently, becomes the moral veil of rationalist thought, and according to Foucault we find it in the 'institutionalism of silence', and its transfer will also be seen in psychology, which is still not liberated from moral chains. The pastoral 'truth of truth' for the good Catholic will be secularized in finding the perfect man. In the modern world, we find pastoral techniques multiplied everywhere, from the police, criminal justice and social workers to the clinic, psychologist and psychiatrist: ${ }^{29}$ and in the same line of thought American psychiatrist Thomas Szasz claims:

"Modern psychiatry ideology is an adaption - to scientific age - to the traditional ideology of Christian Theology (...) in the age of faith ideology was Christian, the technology clerical, the expert priestly, in the age of madness ideology is medical, the technology clinical and the expert psychiatric." 30

It seems that every archive of the individual has been surveyed to the extent of what Foucault later warns: that we are easily detected from the binomial power/knowledge. This presumption leads to the fourth moment, the arrival of Freud, who was still cloaked in psychiatry, but gave up the segregation logic of the asylum, although Merquior notes that "he has a blurred vision regarding sanity and madness but sees it as a bridge to his concept of neurosis". ${ }^{31}$ Caputo thinks this fourth stage has allowed madness to speak, but has remained foreign to "the sovereign enterprise of unreason". ${ }^{32}$ Foucault asserts:

“... psychoanalysis has not been able, will not be able, to hear the voices of unreason, nor to decipher in themselves the signs of the madman." ${ }^{33}$

\section{Derrida claims that these four phases sum up Foucault's History of Madness:}

“... its theme and its first-person narrator, its author, madness speaking about itself. Foucault wanted to write a history of madness itself, that is madness speaking on the basis of its own experience and under its own authority, and not a history of madness described from within the language of reason, the language of psychiatry on madness - the agonistic and rhetorical dimensions of the preposition on overlapping here - on madness already crushed beneath psychiatry, dominated, beaten to the ground, interned, that is to say, madness made into an object and exiled as the other of a language and a historical meaning which have been confused with $\log 0$ itself." 34

The stages mentioned above are the cosmos of madness which extends the historical roots; not of history as a spirit, but history as a story of dissociation and liberation. 
I claim that language is the link between madness and literature. Before discussing literature, we will focus on the language of madness which occupies an important place in Foucault's thought. Madness as the "absence of work/ production" 35 historically was always suppressed and its language was always seen with a double character. Firstly, that of a lack of eloquence, which

cartes, through cogito ergo sum, stratifies the gap between madness and reason, denying the existence of the one who does not think. It follows that from the dialogue on creativity, the mad becomes invisible to classical rationalism, and seems that this historical moment creates the platform for the 'perfect world'. What does the concept the perfect world mean? It is the secularized version of theological premises and an example for this conceptual transformation is the transition from the theology of history to the philosophy of history. A focal point is Descartes' mark of the mental (term coined by Richard Rorty - Richard Rorty, Philosophy and Mirror of Nature, Princeton University Press, Princeton - New Jersey 1980 , p. 17), that defenestrates madness from the 'perfect world' as abnormal/ amoral/unreasonable/delirious. This rationalist-created milieu is transmitted as Enlightenment's platform for cleansing the 'dark mind' of madness once and for all; this cleansing, metaphorically speaking, from an historical perspective could be visualized with the transition from 'ship of fools' as hope for purification of soul in asylum that, for Foucault and Goffman, signifies dehumanization (for more detailed reading about the problematic of asylums I recommend the book by Erving Goffman, Asylums: essays of social situation of mental patients and other inmates, Anchor Books, New York 1961). The pattern will be followed by 'secular religions' (a concept that we can find in different variations, for example: Edgar Morin, Penser L'Europe, Galimard Education, Paris 1990; George Steiner, Nostalgia for the Absolute, Annasi Press LTD, Toronto 2004; Astrit Salihu, Aporitë e Modernes (Kritika e rëfimëve të mëdha), Qendra për studime humanistike "Gani Bobi", Prishtinë 2009; Blerim Latifi, Metafizika e Emancipimit: Ideja e emancipimit në historinë e mendimit perëndimor, Akademia e Shkencave dhe Arteve të Kosovës, Prishtinë 2016). Marxism too will be greatly criticized by Foucault, especially the idea of fetish being related to the perfection of the humanities. Derrida's concerns regarding Foucault's History of Madness would inspire Foucault to write two of his seminal books, The Order of Things: An Archeology of the Human Sciences, in which he proclaims "the death of man" and decomposes the subject-centric view present from Descartes to Hegel, and The Archeology of Knowledge that marks the end of Foucault's archeological period and opens the doors for the genealogical period. The concept of subject-centric(ism) is coined by Astrit Salihu. Cf. A. Salihu, Aporitë e Modernes.

20

Cf. René Descartes, Meditations on First Philosophy, translated by John Cottingham, Cambridge University Press, Cambridge 1996.

21

Shoshana Felman, Writing and Madness (Philosophy/Literature/Psychoanalysis), translated by Martha Noel Evans, Shoshana Felman, Stanford University Press, California 2003, p. 39 .

22

Ibid., p. 38 .

23

Michel Foucault, History of Madness, translated by Jonathan Murphy, Jean Khalfa, Routledge, New York - London 2006, p. 131.

24

John Caputo detected in Greek antiquity that nothing articulated was excluded from logos, so the historical reference where madness is articulated in its form has roots in Middle Ages. Caputo competently elaborates on some alternative forms within the logos. For example: "The Greeks, by way of contrast, thought of sopbrosyne and hybris as alternate possibilities - of moderation and excess - within logos, but they did not constitute some sphere of exile, of a-logos, outside logos." - J. Caputo, "On Not Knowing Who We Are", p. 237. 25 J. G. Merquior, Foucault, p. 21.

26

Lucian of Samosata was a famous ancient Greek satirist, who was an inspiration for Erasmus. He used the concept of morosoph to denote the other side of philosopher, as William Tooke will state in the footnote explaining the concept of morosoph in the context of Lucian's work: "Morosophs are those antidotes to genuine philosophy impertinent trifles and spectres of the brain with seriousness and gravity, as real objects, and reason in forma upon them, without thinking to inquire a little first of all, whether that which they take for matter. If fact or something ascertained, may not be at a bottom of chimera." - Lucian of Samosata, Alexander Or the False Prophet, 
means repressive silence and secondly, preventing articulation, which means the repression of language. In Foucault, the language of madness has another meaning. It does not seek to be rational language, although it is criticized in this view by Derrida; it is a language that will abrogate the dictates of the 'monologue of reason' to speak in its nothingness, to speak for itself. Felman detected this problem:

“... a language other than that of reason, which masters and represses madness, and other than that of science, which transforms it into an object with which no dialogue can be engaged, about which monologues are vacantly expounded-without ever disclosing the experience and the voice of madness in itself and for itself." ${ }^{36}$

This language, silenced and suppressed ever since, has not been free to be articulated by the realm of meaning, has not been heard; this is the way in which Foucault would challenge rationalism for condemning madness to silence. It is not unintentional that we have begun this paper by explicating the idea of the history of madness as an archaeology because Foucault himself invites us to understand the silence of language as the archaeology of silence:

"My intention was not to write the history of that language, but rather draw up the archaeology of that silence." ${ }^{37}$

We cannot understand repression and oppression if we do not explain it, because, after all, the only means we have to express being is language. Foucault claims:

"Language is our only resource, our only source. It reveals to us in the very hollow of our memories and beneath each of our words, beneath each of those words that gallop through our head, it reveals the majestic freedom of being mad." ${ }^{38}$

The language of madness is the manner and possibility of speaking in the depths of silence; silence that through originality reveals to us our authentic being: ${ }^{39}$ authenticity which derives from the decomposition of the narrative that language has the ultimate right for the expression of our life. Language and madness are closely related, they send us on expeditions to the depths of the "unthinking"; within the Heideggerian dictum, this would mean the "untruth of being". ${ }^{40}$ We can speak only in language and this is compatible with the possibility of being mad, ${ }^{41}$ because madness and language are inseparable in articulating the un-sayable, which is the excretion of nothing; nothing that works in the doubling, tautology of the language of madness, or as Eleanore Kaufman claims:

“... this is about finding not plenitude in the expression of nothingness, but nothingness in the plenitude of expression." 42

The language of madness is hidden in some corners of the creative imagination of man, where his wings are clipped from dehumanizing normalcy there he comprehends the un-sayable, as noted by one of the representatives of anti-psychiatry David Cooper in his book The Language of Madness:

"Madness exists as a veil which consists in the true utterance of un-sayable truth in an unsayable situation." 43

This truth is not the 'Truth of the Truth' we can find in psychiatric institutions, which have legitimized the most dehumanizing practices (such an institution is the Hospital Generale) under the slogan of 'deviation'. As Salihu claims:

“... but within psychiatry and within its institutions this is a violent affirmation where 'deviant' individuals (from: this normality) are subjected to total degradation and dehumanization." ${ }^{44}$ 
Normality through police imperatives in behaviour needs to be synthesized with language imperatives to mark madness as the 'absence of work' and to silence it with the eternal possibility of not speaking again. This resonance and poetic-philosophical radiation on language may seem absurd but it has

in: Lucian of Samosata, The Works of Lucian Samosata, translated by Henry Watson Flower, Francis George Flower, vol. 1, Clarendon Press, Oxford 1905, p. 653. Muhamedin Kullashi uses the concept in the context of Erasmus work The Praise of Folly; Erasmus, by quoting Thales, he will call morosophous, wise fools: "A most ungrateful generation of men that, when they are wholly give up to my party, are yet publicly ashamed of the name, as taking to reproach; for which cause, since in truth they are morotatoi, fools, and yet would appear to the world as wise man and Thales we'll even call them morosophous, wise fools." - Desiderius Erasmus, The Praise of Folly, translated by Hoyt Hopewell Hudson, Princeton University Press, Princeton-Oxford 1970, p. 58.

27

M. Kullashi, Vetëpërkufizimi i Njeriut, p. 116.

28

J. G. Merquior, Foucault, p. 23.

29

Cf. J. Caputo, "On Not Knowing Who We Are", p. 233.

30

Thomas Szasz, Ideology and Insanity. Essays on the Psychiatric Dehumanization of Man, Anchor, New York 1968, p. 5.

31

J. G. Merquior, Foucault, p. 25.

32

M. Foucault, History of Madness, p. 278.

33

Michel Foucault, Mental Illness and Psychology, translated by Alan Sheridan, University of California Press, Berkeley, Los Angeles 1987, p. 69.

34

J. Derrida, Writing and Difference, p. 40.

35

Madness as the 'absence of work/productivity' was originally conceived by a lesser-known French philosopher Jacques Martin, who was friends with Marxist philosophers Luis Althusser and Michel Foucault. According to many interpreters, Foucault uses this definition to commemorate his friend.

36

S. Felman, Writing and Madness, p. 41.
37

M. Foucault, History of Madness, p. xxviii.

38

Michel Foucault, Language, Madness, and Desire: On Literature, translated by Roberto Bononno, University of Minnesota Press, Minneapolis, London 2015, p. 27.

39

The difference between Heidegger and Foucault could be seen in the sense of the ontological order. As Webb claims: "The history of the truth of Being as described by Heidegger sees the way Being is disclosed change from one epoch to another, but what does not change is that thinking cannot alter the form of the disclosive event of Being. By contrast, Foucault can be said to preserve the ontological difference while dispensing with the priority of the rules of givenness at any time." However, Webb detects that Heidegger's perspective on the temporal understanding of Being in discontinuity of history of truth of Being differs very little from Foucault's perspective in the sense that he addresses his own finitude prevailing the conditions of the factical life and it's a urge to "modify our relation to the conditions that make us what we are". - David Web, "Martin Heideger", in: Leonard Lawlor, John Nale (eds.), The Cambridge Foucault Lexicon, Cambridge University Press, Cambridge 2014, pp. 630-638, p. 638.

40

Cf. Martin Heidegger, Basic writings from "Being and time" (1927) to "The Task of thinking" (1964), translated by David Farrell Krell, Routledge, London 1993.

41

M. Foucault, Language, Madness, and Desire, p. 27.

42

Eleanore Kaufman, The Delirium of Praise: Bataille, Blanchot, Foucault, Deleuze, Klossowski, The John Hopkins University Press 2001, p. 64 .

43

David Cooper, The Language of Madness, Penguin Books, Reading 1980, p. 23.

44

Astrit Salihu, Postmoderna e interpretuar për shqiptarët, Qendra për studime humanistike “Gani Bobi”, Prishtinë 2005, p. 216. 
also received recognition from philosophers who deal exclusively with language, like Wittgenstein and Rorty, who have pointed out the silent language in academic grids. Language is a sweet madness (Nietzsche) and will remain as such a tool that serves us in decomposing a one-dimensional reading of the world.

It is hope at the end of a tunnel that this silent language will be expressed. All scholars of Foucault and he himself see literature as the hidden space where madness speaks. After all, the prelude to the history of madness and its language is the moment to present literature as a place where the two meet, or as Foucault asserts:

“... that literature was at bottom merely a fact of language and that madness was a signifying phenomenon. That both of them, as a result, played with signs, played with those signs that play with us." ${ }^{45}$

Literature has a thought in its madness; this thought holds it in suspense within a transgressive line. By showing us the other side of the utopian happiness of humanity, literature awakens us to say 'yes' to life, in fact it requires a kind of hyper-morality ${ }^{46}$ from us to understand it. Literature is autonomous both from the logos of thought and the pathos of madness. It is in literature that Foucault will find his explicative instance between logos and pathos. ${ }^{47}$

\section{Literatura Insanitatem}

"Madness and literature may be, for us, like the sky and the earth joined all around us, but connected to one another by a kind of large opening in which we continue to advance, in which, in fact, we speak, we speak until the day they place a handful of dirt in our mouth." ${ }^{\$ 4}$

Before we make the connection among language, literature and madness, we must briefly define what language means to Foucault. He sees language through a self-reflective schema: 1) as Discourse and 2) as the Language of Literature. ${ }^{49}$ As discourse, it manifests itself within discursive formations or epistemes that unfold as finitude, while as the language of literature it tries to manifest to us the most authentic part of being or, in Foucault's words, "raw being". On the one hand there is the connection of language with the institutionalized discursive formations within a kind of logophilia, while on the other hand there is the transgressive power of the 'language of literature' to articulate non-eloquence and the poverty of madness. ${ }^{50}$ Repressed and silenced speech acts take shelter in the 'language of literature', and we know them as "anonymity of murmur" ${ }^{51}$ or as "multitude of voices". ${ }^{52}$ The metaphorical language of literature is itself the pathos of madness. This symbiotic connection between literature and madness manifests the power of the lost articulation of the repressed voice. Perhaps the same fatum haunts both literature and madness, and it is the fate of exclusion and isolation. At this point, it seems that Foucault himself is attentive, because in both (récit's) histories, that of madness as thought and literature, he detects the characters who pointed out this exclusion. In the first camp, there is Nietzsche, ${ }^{53}$ who according to Foucault finds it impossible to realize the Dionysian philosopher ${ }^{54}$ within the systematic schemes of rationality, while in literature there is the transgressive power of articulation or, as Foucault characterizes it, "being in language" 55 as a kind of externality that creates a vortex and void where language and speech multiply itself into infinity. ${ }^{56}$ When we talk about the void, Evans asserts that: 
"Language creates this void through dispersing the subject who would speak it, "multiplying [the subject] within the space created by its absence (...).",57

The silence and murmur of madness can be outlined and understood within this "ontology of literature", so Foucault himself emphasizes the authors affected by the hand of madness who do not agree with the conventions of what is known as 'normal', such as "De Sade, Artaud and Dostoyevsky". Foucault claims they turned morality and metaphysical embarrassment to the human glory of immanence:

“... to wait two centuries before Christ found once more the glory of his madness in Dostoevsky and Nietzsche, when scandal regained its power of manifestation and unreason ceased being nothing more than the public shaming of reason." 58

The connection between literature and madness can probably be understood from two perspectives: one is metonymic, with a constant reference to madness in literature, while the other is metaphorical, replacing literature in use via the association to madness. Thus, the first is contiguous and the second is substitutive. ${ }^{59}$ Another reading of the relationship between literature and madness would be regarding the meaning of that 'triangulation' or meeting place

45

M. Foucault, Language, Madness, and Desire, p. 38 .

46

Cf. Georges Bataille, Literature and Evil, translated by Alastair Hamilton, Penguin Books, London 2012.

47

Cf. S. Felman, Writing and Madness, p. 51.

48

M. Foucault, Language, Madness, and Desire, p. 38 .

49

Fred Evans, "Language", in: Leonard Lawlor, John Nale (eds.), The Cambridge Foucault Lexicon, Cambridge University Press, Cambridge 2014, pp. 236-242, p. 236.

50

When we talk about language poverty, we are referring to the potential for proliferation and reproducing meanings in it. In its silence, in an unarticulated murmur, madness creates spaces of expression which have a creative richness, where "the word speaks for itself" (Michel Foucault, Fearless Speech, edited by Joseph Pearson, Semiotexte, New York 2001). As Gilles Deleuze asserts: "The poverty of language must become its very source of wealth." - Gilles Deleuze, "Raymond Roussell, or The Abhorrent Vacuum", in: Gilles Deleuze, Desert Island and Other Texts 19531974, translated by Michael Taormina, Semiotexte, New York 2002, p. 73.

51

Michel Foucault, "Language to Infinity", in: James D. Faubion (ed.), Essential Works of Foucault 1954-1984, vol. 2, "Aesthetics, Method and Epistemology", The New Press, New York 1998, pp. 89-101, p. 91

52

M. Foucault, The Archeology of Knowledge, p. 222.

53

According to Felman, while Hegel tries to instill madness within thought (this aspect is also noticed by Foucault when he states that there is a kind of liberation in the Phenomenology of Spirit), Nietzsche tries to put thought into madness. Cf. S. Felman, Writing and Madness, p. 36.

54

M. Foucault, History of Madness, p. 237.

55

Michel Foucault, "The Thought of the Outside", in: James D. Faubion (ed.), Aesthetics, Method and Epistemology: Essential Works of Foucault 1954-1984, The New Press, New York 1998, pp. 148-169, p. 149.

56

F. Evans, "Language”, p. 238.

57

Ibid., p. 239.

58

M. Foucault, History of Madness, p. 153.

59

S. Felman, Writing and Madness, p. 48. 
between literature, literary work and language. The triangulation thesis is not valid in the relationship between literature and madness, its focus is only in answering the question of "What is literature?". One thing is for sure: the language of literature lies within the bounds of madness because only there does it have the freedom to express itself in its immorality. The two perspectives mentioned above are nothing more than a marking of the ubiquity of madness in literature. ${ }^{60}$ Excluded from rationalist philosophy, madness will find its place in literature, as the Felman claims:

“... excluded from philosophy, madness is indeed to some extent contained in literature, it by no means constitutes its content." 61

To make this relationship between literature and madness more tangible, we have selected three authors who, referring to Foucault, point out the manifestation of the "lyrical liberation" of madness. These are the authors mentioned above: Dostoevsky, De Sade, Artaud. As long as the world has produced manifestos for a bright future, these literary works and these authors have produced manifestos for the dark present that in a broad sense could be seen as a negation (transgression itself is also an affirmative negation), the authors presented in this paper and most of their works were written inside the walls of asylums and hospitals. Their work is a kind of narration from inside the walls.

These manifestations will be named as follows: Anti-Moral Manifesto (Dostoevsky), Licentious Manifesto (De Sade), Un-Reason Manifesto (Artaud). Besides the reasons mentioned above, the common denominator of the protagonists of the novels in question is "ontological insecurity". ${ }^{2}$ Within this insecurity, one can testify to the non-verbal murmur of madness and thought in the un-thoughtful. This silence that speaks for itself seems to have its roots in Heidegger and his concept of 'language speaks'; this Heideggerian root in the modified version of Foucault shows us as "the language of literature that speaks for itself", ${ }^{63}$ so in this "ontological insecurity" an "ontology of literature" 64 is created, and it seems that we have it there as well mise en scène where madness dwells. In literature we find proliferation of disparate forms of the word in its being. ${ }^{65}$ The words dwell freely in their expressive selfness disburdened by unheimlich ${ }^{66}$ (Freud). As the philosopher David Scott claims in his literary work:

"What is the work of literature other than opening language to 'this strange thing inside', where literature discovers the impetus for its mode of expression; it is here where literature 'constitutes a space of its own', where 'language dwells on itself'. And so modernity in literature is identified by the practice it carries out, which bestows upon language a depth." ${ }^{67}$

\section{A) Anti-Moral Manifesto (Dostoevsky)}

"Every knowledge is a disease", says Dostoevsky's Underground Man as a sign of revolt against the institutionalization of life and as a rejection of the moral grid, which as a moral instrument is known as the "categorical imperative" and as a discipline in the philosophy of morals is known as deontology. This is not just a phraseological statement; it shows the cold atmosphere of the city and the state the author comes from; it seems that he also expresses the gray colours of that place - to use the architect Norberg-Schulz's term, he is his genius loci. ${ }^{68}$ Thus, the spirit of the place implies a kind of demolition of all moral values that presuppose a kind of metaphysical resentment. The 
Underground Man is not a fictional character, but Dostoevsky in a fictionalized variant; they can be separated only if the author does not confirm them, or, as the literary critic George Steiner claims:

"Dostoyevskian summa - even if we grant that the narrator's views cannot be identified with the novelist." ${ }^{\circ 9}$

The relativistic moral attitudes in Dostoevsky's work could be seen as kind of proto-existentialism. Kaufman in his work sees how Notes from Underground preceded existentialism, even though existentialism is an ambiguous term, as author warns. ${ }^{70}$ At the same time, Dostoevsky's critique is a radical critique of social philosophy, because there he sees correlations between rationalism, morality and law, as sophisticated form of Reason apparatus. Reason apparatus through engineering a system morality made body the holder of scars from punishment that comes from moral justice. Dostoevsky tends to emphasize the difference between the social norm "sick" and biological norm "sickness", as Caputo also claims:

"... and here it means the unmaking and destruction of the world that reason builds around itself." "'1

This is an interesting premise that connects the novel with the history of madness, because it manifests most of the punishments or signifiers from medical discourse known as 'mental illness', as claimed by Thomas C. Fiddick:

“... in Notes from Underground parallel numerous modern notions about mental illness, especially the concepts of the obsessive compulsive, masochist, paranoid, schizophrenic, epileptic and 'detached neurotic', but also the sadism of displaced hostility." 72

60

M. Foucault, Language, Madness, and Desire, p. 38

61

S. Felman, Writing and Madness, p. 50.

62

Cf. Ronald David Laing, The Divided Self: An Existential Study of in Sanity and Madness, Penguin Books, London 1990.

63

F. Evans, "Language”, p. 241.

64

M. Foucault, "Language to Infinity", p. 92.

65

Michel Foucault, The Order of Things: An Archeology of the Human Sciences, Routledge, New York - London 2002, p. 384.

66

Cf. Sigmund Freud, The Uncanny, translated by David McLintock, Penguin Books, London 2003.

67

David Scott, "The Secret of the Corpse- Language Machine: The Birth of the Clinic and Raymond Roussel", in: David Scott (eds.), Understanding Foucault: Understanding
Modernism, Bloomsbury, New York - London 2017, pp. 39-60, p. 40.

68

Cf. Astrit Salihu, Lexim Filozofik i Arkitekturës, Shoqata e Filozofëve të Kosovës, Prishtinë 2018.

69

George Steiner, Tolstoy or Dostoyevsky, Yale University Press, New York 1996, p. 228.

70

In his book Existentialism from Dostoevsky to Sartre, American philosopher Walter Kaufman claims that not all existentialist philosophers accepted this label. Cf. Walter Kaufmann, Existentialism from Dostoevsky to Sartre, Meridian Books, New York 1975.

71

J. Caputo, "On Not Knowing Who We Are", p. 240.

72

Thomas C. Fiddick, "Madness, Masochism and Morality: Dostoyevsky and His Underground Man", in: Branimir M. Rieger, Dionysus in Literature. Essays on Literary Madness, Bowling Green State University Popular Press, Ohio 1994, pp. 89-101, p. 89. 
The hermeneutics of refusal which characterizes the Underground Man makes it possible to express the freedom of speech act that enables madness, and we will discuss the connection of these two components at the end of the paper. The Underground Man claims:

"See gentlemen, reason does it job good, this could not be denied; nevertheless reason only satisfies reasonable human abilities, whereas desire is complete manifestation of life, meaning all life, including reason and its surroundings." 73

The passage marks radical criticism of external morality as a return to the body towards impulses of life. As long as these morals designed outside of us exist and function, immorality becomes a need and an opportunity to express ourselves freely, as Foucault would claim:

"But throughout the period in which classicism maintained a fundamental choice as the condition for the exercise of reason, madness is revealed in the light of freedom." 74

Man's drama of freedom has its price, the creative eccentricity that is translated as the ritual of exclusion in a normal society. If we contextualize it within Foucault's discourse, the Underground Man's lament would mean a kind of rejection of the psychological knowledge called "mental illness". The dividedness of immunity from society is best illustrated in Dostoevsky's novel, where man experiences moralizing exile, which is one of the main premises of Foucault's critique. In the novel as well as in Foucault's book there is a common denominator - the hermeneutics of refusal. In the first, the character interprets, explains and understands the world through refusal and negation of himself as a species and society as a construct, while the second "rejects the cataphatic discourse on the individual". ${ }^{75}$ The hermeneutics of refusal found in this covalent marriage between literature and philosophy has the function of revealing the re-recognition of madness by literature and medical exclusion by "marking it as a mental illness by extinguishing its pathos" ${ }^{76}$ Thus, any rationalizing knowledge as it ends has the disease, and this is the message of the hermeneutics of refusal which operates with the 'madness within thought' (Foucault).

\section{B) Licentious Manifesto (De Sade)}

The overture to de Sade's book Philosophy in the Bedroom begins with a statement entitled "Licentious", which summarizes de Sade's lucid genius but at the same time outlines his influence on French philosophy:

“... voluptuaries of all ages, of every sex to you alone I have dedicated this work: feed on its principles, for they help your passions." $" 77$

This seems to be the reason why de Sade is considered one of the most paradigmatic writers in literature, because he destroyed all the cultural codes of the society in which he lived, inviting us to the lightness of libidinal experience of the world or the genius of the phallus (Bataille). There are no norms, there are only lusts which are suppressed. In his book History of Madness, Foucault sees de Sade as the imprisoned libertine of passions; the position of libertine is the generic point of man who tries to put passions and desires against rationalizing truths. Libertines are the first to highlight the ethical perception of medical knowledge. De Sade is an example of a libertine who has installed a discourse of passions and desires that highlight the pleasure of a licentious life. 
"Libertinage was a kind of scepticism that demonstrated the constant threat of madness in the search for a reasonable ordering of the heart's passions. But by the second half of the seventeenth century, the libertine's free thinking comes to be seen as a consequence 'of a licentious life'.",78

This ethical perception of medical knowledge has another consequence in society, because at the same time it emphasizes a new form of moral oppression (hiding inner impulses) and it is perceived as "embarrassment" or "shame". Thus, on the one hand it turns out that de Sade is the point of fusion of the two stories Foucault intends to write, which reveals the character of a libertine, a kind of insanitas (not of a sound mind) that has licentiousness in the form of erudition, and on the other hand there is the history of sexuality where de Sade is the point of transition from eros to sexualis or, in other words, the transition from the classical to modern episteme, as he (Foucault) says:

"... before Sade - there was the age of libertinage, and after, the age of sexuality."

An engaging dimension for Foucault is the insistence on non-compromise and commitment to freedom:

"Sade engaged in all his life, for which, as you know, he paid the price of liberty." 80

This price paid by de Sade seems to legitimize a new kind of madness of being aware of one's lucidity, thus acting to achieve some sort of expression of a pure lucid gesture. This gesture of self-destruction, this world of debauchery, seems to belong to the de Sade-type eccentrics, whose inner animal has a kind of mourn for freedom which wants to demystify the limits that every society has built, as Maurice Blanchot claims:

"... that he had known how to make the prison, the image of the loneliness of the universe, but, this prison, this world does not bother him anymore, as he had expelled and excluded all creatures from them." $"$

Through his 'sadism', as Foucault puts it, de Sade tries to expose the destructive and liberating power of the madness of desires. The discourse of Licentious is based precisely on the nakedness not only of the body but also of being; the naked being is not subject to any kind of moral arbitrariness, so as Bataille asserts:

73

Fyodor Dostoevsky, Notes from Underground, translated by Richard Pevear, Larissa Volokhonsky, Everyman's Library, London 1993, p. 38.

74

M. Foucault, History of Madness, p. 153.

75

J. Caputo, "On Not Knowing Who We Are", p. 240.

76

S. Felman, Writing and Madness, p. 50.

77

Marquis de Sade, Philosophy in the Bedroom, in: Marquis de Sade, Justine, Philosophy in the Bedroom and Other Works, translated by
Richard Seaver, Austryn Wainhouse, Grove Press, New York 1965, p. 185.

78

L. Lawlor, D. J. Palumbo, "The Origin of Parrēsia in Foucault's Thinking”, p. 21.

79

M. Foucault, History of Madness, p. 22.

80

M. Foucault, Language, Madness, and Desire, p. 53.

81

Georges Bataille, "Sekreti Sade", in: Marqués de Sade, Filozofia në Odën e Pasqyrave, translated by Hysen Sinani, Zenit, Tiranë 2006, pp. 179-205, p. 191. 
"What destroys a being also liberates it; liberation is, among other things, the destruction of a being who had accepted the limitations of etiquette. Nudity is the fragmentation of these limitations." $" 82$

The West cannot be understood without de Sade; he is responsible for switching from ars erotica to scientia sexualis. ${ }^{83}$ This transition will change the Victorian world of Reich once and for all. The subconscious dream is already appearing to us through the delirious mourns excitation.

\section{C) Un-Reason Manifesto (Artaud)}

Within Foucault's concept, Antonin Artaud "is the name that madness could be understood" $" 84$ in the purest form of gesture. Glory to cruelty, gesture to non-articulated forms of language that Jacques Derrida comments:

"Glosopedia, which is neither an imimitative language nor a creation of names, takes us back to the borderline of the moment when the word has not yet born." ${ }^{85}$

This is also related to the language of madness as a silent form of non-eloquence which is replaced by the articulation of un-reason. This lack of work (oeuvre) is the point of connection between Artaud and Foucault; it also unites the possibility of forming a language of cruelty by duplicating it into a new form. The first component of duplicated new form, which we call "language of cruelty" (where it roots could be found in Artaud's "theatre of cruelty"), is gesture as the form of articulating the un-sayable. The second component is a language autonomous from epistemological and semantical formations. In this 'language of cruelty', literature and language create milieu that is not strange for ether of them, as Foucault claims:

"There in this pale region, in this essential hiding place, the twin incompatibility of work and madness is revealed; it is the blind spot of each of their possibilities and of their mutual exclusion. But since Raymond Roussel, since Artaud, it is equally the place where language and literature approach each other" 86

This is the "language of absence" (Foucault) where emptiness is essential and from which new forms of expression are outlined. Where there is nothing reasonable in the impossible, there is freedom to eliminate thought. For Artaud, all this cruel presence also has moments of insecurity; in fact, insecurity is the main impulse to embrace these lucid adventures through language.

“... this is the only use language can now serve. A vehicle for madness, for the elimination of thought, for rupture, the maze of unreason." $" 87$

The Oeuvre of Artaud is built through delirious language. There is also the possibility of combining the spaces between madness and work; the first as a lack of work and the second as an opportunity to understand the first. When we say this, we mean that Artaud's work and especially his book Van Gogh: the man suicided by society is a radical critique of socious ${ }^{88}$ - a normal, sick society that has the invention of psychiatry as its only skill. ${ }^{89}$ The same line of thought is followed by Foucault's radical critique of the society of normality. Therefore, the absence of work in them should be marked as a kind of opportunity for creativity. Perhaps the best description of Artaud's work (oeuvre) is his own maxim: 
It seems that the horizon or space where we experience an aesthetic piece of madness is in the arts. This is also Foucault's approach in his book but with a more forced pathos that is often criticized. If Bosch, Van Gogh and Goya are the face of madness, then we can freely conclude that literature is their story, because only through literature we could find autonomous spaces where we could be free from the cruelty of rationality. Hence, the axiom 'normality is not normal' shows this attempt to speak freely, as the philosopher Merquior asserts:

"Their body was in chains, but their mind had wings - wings later clipped by the despotism of reason." 91

In the coming centuries, society will be more oppressive than asylums and psychiatric institutes. $^{92}$

\section{Conclusion}

“"Man' signifies 'Thinker'

There lies madness." [Friedrich Nietzsche] ${ }^{93}$

Foucault has the role of a heretic whose mission seems to be to dissipate the glow of light by teleporting us to basements and alleys without light. If we speak the language of bio-politics, ${ }^{94}$ this is where man first faces oppression

82

Ibid., p. 191.

83

Michel Foucault, The History of Sexuality Volume I: An Introduction, translated by Robert Hurley, Pantheon Books, New York 1978, pp. 77-78.

84

Edward Scheer, "Foucault/Artaud: The Madness of the Oeuvrein", in: Clare O' Farrell (ed.), Foucault: The Legacy, Queensland University of Technology, Kelvin Grove (Brisbane) 1997, pp. 17-27, p. 19.

85

J. Derrida, Writing and Difference, pp. 302303.

86

M. Foucault, History of Madness, pp. 582583.

87

According to: M. Foucault, Language, Madness, and Desire, p. 39.

88

Cf. Antonin Artaud, Van Gogh $i$ vetëvrari $i$ shoqërisë, translated by Idlir Azizi, Zenit, Tiranë 2013.

89

E. Scheer, "Foucault/Artaud", p. 24.

90

Antonin Artaud, "Here Lies", in: Antonin
Artaud, “Antonin Artaud Anthology", Jack Hirschman (ed.), City Light Books, San Francisco 1965 , pp. 238-247, p. 238. The part cited is translated by Jack Hirschman and F. Teri Wehn.

91

J. G. Merquior, Foucault, University of California Press, Berkeley - Los Angeles 1985, p. 26.

92

We will see how society will become more repressive than psychiatric institutes; a spark of this psychiatric reform can be found in the works of Italian psychiatrist Franco Basaglia, who, under the influence of Foucault and Goffman, would reform the psychiatric system in Italy under the famous law known as "Law 108", which is a derivative of his earlier attempt at "Democratic Psychiatry". Cf. Nancy Scheper-Hughes, Anne M. Lowell (eds.), Psychiatry Inside Out: Selected Writings of Franco Basaglia, translated by Anne M. Lovell, Teresa Shtob, Columbia University Press, New York 1987.

93

Cited after: S. Felman, Writing and Madness, p. 22.

94

Cf. Roberto Esposito, Bios, translated by Timothy Campbell, University Minnesota Press, Minneapolis - London 2008. 
of man and then society/community, where man loses all immunity in relation to society. Foucault is a transgressive archivist who tries to highlight those stories that official discursive formations have tried to suppress. The History of Madness is the moment of shifting thought from transcendence to immanence. The History of Madness seems to mark the new axes of Foucault's career, the ones that will later on define his thinking, namely power, knowledge and ethics. ${ }^{95}$ So, the premises of the 'history of madness' will be catapulted and outlined in his later work. A consequence of this connection and thinking consistency is his concept of "disease of power", which he sees throughout the whole political spectrum; he also sees the discourse of 'exclusion' within the power games of normalcy, especially in "Marxland", which in its most brutal and perverse form is manifested in Stalinism, but also "Vaterland", which is manifested in the same forms as fascism:

“... 'diseases of power' - fascism and Stalinism - that the twentieth century has known (...). Are we to think that these are 'alienated power', power gone wrong, power that divests human beings of something unalienated or even inalienable? Foucault says they are marked by an 'internal madness', but that such madness is merely the extension of contemporary 'political rationality', of a kind of unlimited rationalization." 96

\section{Lyotard has a similar statement, but from the perspective of postmodernism:}

"We can understand Auschwitz as a pragmatic name for the tragic 'irreversibility' of modernity." 97

The need to shift from rationalism and the search for habitats that are not illuminated by the transparency of the mind has sent Foucault into the asylum space, into the unreasonable which is related to his later concept of parressia (to speak freely). We can conclude that the connection between the un-reasonable and parrēsia is found in literature, because in literature you can speak freely, which explicitly implies parrēsia, and you can find silence as a murmur of un-reason. The first is "the highest exercise of freedom", ${ }^{98}$ while the second is a kind of originator of "absolute freedom". ${ }^{99}$ It is no coincidence that only in literature is rationalism shattered by the unreasonable, and on the other hand the capillarity of power becomes apparent as an opportunity for parrēsia, which in the Roman language would be translated as libertas as a kind of intensification of freedom. ${ }^{100}$ Only literature makes possible "the highest exercise of freedom", where the lone / lunatic / mad dwells on the endless possibility of experiencing self-liberation. This whole complex map of thought has followed a line that Merquior would call "neo-anarchism", not in the sense of the vernacular vocabulary but in the authentic sense of rejecting any form of government over human life. Literature will remain the only place where the noise of madness is felt; the place where being in its own lust whistles the harmonious melody of its dissonance. 


\title{
Labinot Kelmendi
}

\section{Ludilo i književnost: Foucaultov okršaj}

\begin{abstract}
Sažetak
Svrha je priloga ocrtati vezu među književnošću, ludilom i jezikom u Foucaultovoj filozofiji. U prvom dijelu rada tri se diskurzivne baze smještaju u »kozmos ludila u u smislu kako to Serres zove »arheologija psihologije«, a Caputo »dekonstrukcija psihologije». Ovaj dio obilježava jezik književnosti kao prostor dekomponiranja »tribunala cogita (Derrida). Drugi dio eksplicira impetus »jezika književnosti«, nastojeći promicati lunatičke manifestacije Dostojevskog, De Sadea i Artauda, te kako njihovi radovi imaju simbiotičke veze s Foucaultovim radom. Rad završava raspravom o nerazumnom i parrēsiji kao prilici koja se može pojaviti samo u književnosti kao mjestu opstojanja. Konačno, kako Foucault bilježi, »jezik književnosti« jest »jezik ludila« ili mogućnost slobode izražavanja našega Bitka.
\end{abstract}

\section{Ključne riječi}

Michel Foucault, ludilo, književnost, jezik, parrēsia, nerazumno

\section{Labinot Kelmendi}

\section{Wahnsinn und Literatur: Foucaults Auseinandersetzung}

\begin{abstract}
Zusammenfassung
Der Zweck des Beitrags ist es, den Zusammenhang zwischen Literatur, Wahnsinn und Sprache in Foucaults Philosophie zu schildern. Im ersten Teil der Arbeit werden drei diskursive Grundlagen in den „Kosmos des Wahnsinns“ gestellt, in dem Sinne, wie Serres es die „Archäologie der Psychologie “ und Caputo es die „Dekonstruktion der Psychologie“ "nennt. Dieser Teil kennzeichnet die Sprache der Literatur als einen Raum für die Dekomponierung des , Tribunals des Cogito" (Derrida). Der zweite Teil expliziert den Impetus der "Sprache der Literatur", indem er die lunatischen Manifestationen von Dostojewski, De Sade und Artaud sowie die symbiotischen Verbindungen ihrer Werke zum Werk Foucaults zu akzentuieren trachtet. Das Paper schließt mit einer Erörterung über das Unvernünftige und die Parrhesie (parrēsia) als Gelegenheit, die lediglich in der Literatur als dem Ort des Fortbestands auftauchen kann. Letzten Endes, wie Foucault es notiert, ist die ,Sprache der Literatur “ eben die ,Sprache des Wahnsinns “ oder die Möglichkeit zur Ausdrucksfreiheit unseres Seins.
\end{abstract}

\section{Schlüsselwörter}

Michel Foucault, Wahnsinn, Literatur, Sprache, parrēsia, das Unvernünftige

95

L. Lawlor, D. J. Palumbo, “The Origin of Parrēsia in Foucault's Thinking”, p. 21.

96

J. Caputo, "On Not Knowing Who We Are", p. 247.

97

Cf. Jean-François Lyotard, The Postmodern Explained to Children: Correspondence, 1982-1985, translated by Julian Pefanis, Morgan Thomas, Turnaround, London 1992.

\section{8}

Michel Foucault, The Government of Self and Others. Lectures at the College de France 1982-1983, translated by Graham Burchell, Palgrave Macmillan, New York 2010, p. 67.

99

M. Foucault, History of Madness, p. 157; L. Lawlor, D. J. Palumbo, "The Origin of Parrēsia in Foucault's Thinking”, p. 22.

100

Ibid. 


\section{Labinot Kelmendi}

\section{Folie et littérature : l'escarmouche de Foucault}

\section{Résumé}

L'objectif de ce texte est d'établir un lien entre la littérature, la folie et le langage dans la philosophie de Foucault. La première partie du travail institue trois bases discursives dans le " cosmos de la folie » au sens de " archéologie de la psychologie " comme l'entend Serres, ou de "déconstruction de la psychologie », selon Caputo. Cette partie caractérise le langage de la littérature comme espace de décomposition du «tribunal du cogito » (Derrida). La deuxième partie explicite l'impetus du «langage de la littérature » visant à promouvoir les manifestations lunatiques de Dostoïevski, du Marquis de Sade et d'Artaud, et la manière dont leurs travaux présentent un lien symbiotique avec le travail de Foucault. Le travail se termine par une discussion sur le déraisonnable et la parrêsia comme occasion qui peut faire son apparition seulement dans la littérature en tant que lieu d'existence. Enfin, à la manière dont Foucault le caractérise, "le langage de la littérature " est le " le langage de la folie » ou la possibilité de liberté d'expression de notre Etre.

\section{Mots-clés}

Michel Foucault, folie, littérature, langage, parrêsia, déraisonnable 